\title{
Zircon-Baddeleyite Age Relationships in a Polymict Lunar Breccia
}

D. M. VANDERLIEK ${ }^{1}$, H. BeCKeR ${ }^{1 *}$, A. ROCHOLL ${ }^{2}$, W.H. SCHWARZ $^{3}$

${ }^{1}$ Freie Universität Berlin, Institut für Geologische Wissenschaften, Malteserstr. 74-100, D-12249 Berlin, Germany, (*hbecker@zedat.fu-berlin.de)

${ }^{2}$ Geoforschungszentrum Potsdam, Telegrafenberg, D-14473

Potsdam, Germany, (alexander.rocholl@gfz-potsdam.de)

${ }^{3}$ Universität Heidelberg, Inst. f. Geowissenschaften, Im Neuenh. Feld 234-236, D-69120 Heidelberg, Germany

Understanding the behavior of the U-Pb system in zircon $(\mathrm{Zr})$ and baddeleyite $(\mathrm{Bd})$ in lunar rocks becomes increasingly important for unravelling the late bombardment history of the Moon. Here, $\mathrm{Pb}-\mathrm{Pb}$ ages (typical $2 \mathrm{sd}=24 \mathrm{Ma}$ ) and the formation history of $<20 \mu \mathrm{m} \mathrm{Zr}$ and $\mathrm{Bd}$ grains in the polymict plagioclase rich impactite $67915(76,, 84)$ from the Imbrian Descartes Formation are discussed to provide a better understanding of the response of $\mathrm{Zr}$ and $\mathrm{Bd}$ in lunar breccias to impact-related heating.

67915 comprises a heterogeneous clast population of different sizes and composition (anorthosites, noritic anorthosites, troctolites, sodic ferrogabbro) in a fine-grained comminuted plagioclase rich matrix. Most $\mathrm{U}-\mathrm{Pb}$ ages of $\mathrm{Zr}$ appear to be concordant while few $\mathrm{Bd}$ and $\mathrm{Zr}$ are reverse discordant. Different textures of $\mathrm{Zr}$ and $\mathrm{Bd}$ in this sample can be distinguished: (1) Subhedral Bd intergrown with ilmenite (Ilm) in the matrix yield the oldest ages (4.27-4.24 Ga, $\mathrm{n}=3$ ) either reflecting growth of $\mathrm{Bd}$ during cooling of magmatic ilmenite or exsolution of $\mathrm{Bd}$ from Ilm after impact metamorphism. (2) Similar ages (4.24 Ga, $n=3)$ are shown by $\mathrm{Bd}$ and $\mathrm{Zr}$ associated with $\mathrm{SiO}_{2}-\mathrm{K}$-feldspar (Kf) bearing clasts, in which $\mathrm{Bd}$ is partially replaced by $\mathrm{Zr}$. Local melting of $\mathrm{SiO}_{2}$ due to shock heating resulted in these replacement textures. (3) Matrix and $\mathrm{Kf} \pm \mathrm{SiO}_{2}$ bearing clasts also contain subhedral $\mathrm{Zr}$ and $\mathrm{Bd}$ (without $\mathrm{Ilm}$ ) showing identical ages (4.24-4.23 Ga. $\mathrm{n}=7$ ). (4) Somewhat younger, poikilitic $\mathrm{Zr}$ (4.23-4.20 Ga, $\mathrm{n}=9$ ), commonly occurs in the matrix and in $\mathrm{SiO}_{2}-\mathrm{Kf}$ bearing impact melt clasts containing $\mathrm{Fe}-\mathrm{Ni}$ metal. (5) A granular zircon aggregate in the matrix (4.20 Ga, $\mathrm{n}=1)$ contains tiny relic Bd (?) inclusions. (6) A rare poikilitic Bd$\mathrm{Ilm}$ intergrowth in the matrix yielded a date with large uncertainty that is difficult to interpret $(3.8 \pm 0.6 \mathrm{Ga})$.

Our data on 67915 are consistent with impact-related heating events at $\geq 4.27 \mathrm{Ga}, 4.24 \mathrm{Ga}$ and perhaps $4.20 \mathrm{Ga}$. The results indicate that the $\mathrm{U}-\mathrm{Pb}$ systems in $\mathrm{Zr}$ and $\mathrm{Bd}$ were not disturbed by the $3.9 \mathrm{Ga}$ old Imbrium impact. 